\title{
4
}

\section{A SYSTEMIC APPROACH TO THE DECOLONISATION OF KNOWLEDGE}

\section{Implications for scholars of development studies}

\author{
Sarah Cummings, Nyamwaya \\ Munthali, and Peter Shapland
}

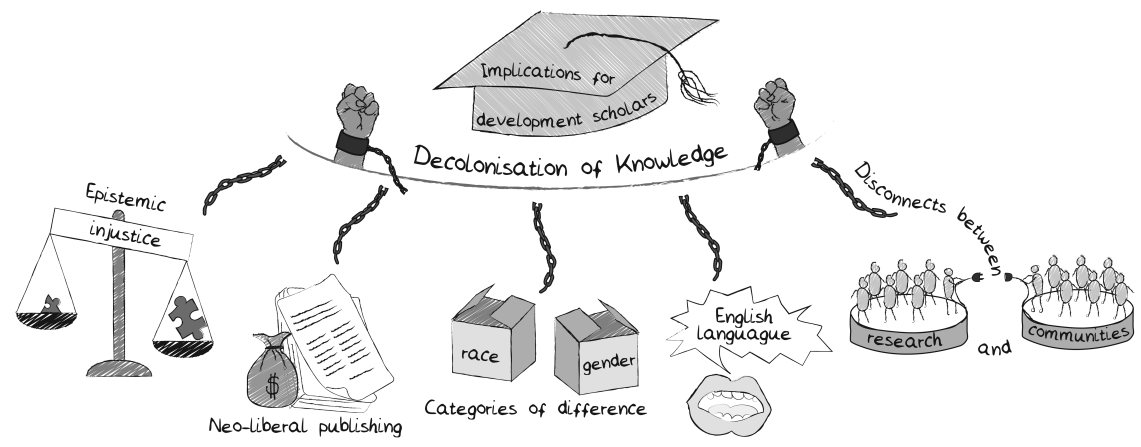

\section{Introduction}

The academic world has experienced a 'visible resurgence of decolonisation/ decoloniality' evident in many recent publications (Bumpus, 2020; Demeter, 2020; Doharty et al., 2021; Istratii and Lewis, 2019; Ndlovu-Gatsheni, 2019; Pailey, 2020; Patel, 2020) that build on the work of others (Busia, 1960; Mafeje, 1978; Nkrumah, 1961; Okot p'Bitek, 1997; Said, 1979). Decolonisation of knowledge is a group of processes and actions that intentionally dismantle the entrenched, unequal patterns of knowledge creation and use that emanate from our colonial past; it is a process full of 'complexities, tensions and paradoxes' (Oliveira Andreotti et al., 2015, p. 22). Given that decolonisation of knowledge has been criticised as being 'an intellectual rather than a political project' (Broadbent, 2017), we aspire to make an important contribution to the overall decolonisation process by emphasising the importance of action, suggesting how scholars of development studies can 'walk the walk' on the decolonisation 
of knowledge. To bring about change, we need activism and transformational knowledge which 'challenges each of us not to stop at the analysis, to oppose the status quo, to devise innovative solutions, and to include reflexivity and meta-learning.' ${ }^{1}$

In this chapter, we employ a systems perspective to investigate how coloniality is manifested in the current academic knowledge system and how we can make progress toward the 'decolonisation of knowledge.' We reflect on how individual scholars located in Western donor countries, who benefit from the coloniality of the current knowledge system, can undermine and contest this coloniality with their research and activism, resonating with Pailey's (2020, p. 742) statement that 'Until white development workers and scholars confront how they benefit from the racial hierarchies that underpin this field, and actively work to upend their unearned privilege, development will always suffer from a "white gaze" problem.' As we will discuss later, although we recognise that decolonisation is an ethical issue, we contend that cognitive diversity represents progress and improvements to our pool of knowledge.

\section{Development studies and coloniality}

The field of development studies focuses primarily on institutional and structural changes in formerly colonised countries, including empirical and normative concerns: how social change occurs, and what changes should occur (Kothari, 2019). Numerous scholars have shown how the international development project emerged directly out of colonialism, as a continuation of colonialist discourses (Chandra, 1992; Cooke, 2003; Goldsmith, 1997; Kothari, 2019; Miege, 1980). Although the 'good intentions' of development practitioners and researchers are an intrinsic part of development studies, these intentions tend to conceal the colonial roots of international development via the "dichotomy between a colonialism that is "bad," exploitative, extractive and oppressive and a development that is "good," moralistic, philanthropic and humanitarian' (Kothari, 2019, p. 51). Against this background, 'coloniality' can be understood as the entrenched power dynamics and patterns of knowledge creation and use that have emerged from the accidental historical power relations of colonial domination. The term 'coloniality' was first used by Mignolo (1995) according to Torres (2007, p. 243):

Colonialism denotes a political and economic relation in which the sovereignty of a nation or a people rests on the power of another nation, which makes such nation an empire. Coloniality, instead, refers to long-standing patterns of power that emerged as a result of colonialism, but that define culture, labour, intersubjective relations, and knowledge production well beyond the strict limits of colonial administrations. Thus, coloniality survives colonialism. It is maintained alive in books, in the criteria for academic performance, in cultural patterns, in common sense, in the selfimage of peoples, in aspirations of self, and so many other aspects of our 
modern experience. In a way, as modern subjects we breathe coloniality all the time and everyday.

All of us, Western scholars and marginalised groups alike, internalise or 'breathe' dominant knowledge structures via the learning and utilisation of categories that act as the elementary building blocks of cognition (Arce and Long, 1987). Some scholars argue that the categories that we currently use in development studies (such as the Global North and South, modern and traditional knowledge, formal and informal institutions, etc.) emerged from disempowering or 'othering' distinctions made by the colonial discourse (for example, McEwan, 2009).

The coloniality of knowledge is exemplified by specific knowledge being prioritised over other knowledges (Heleta, 2018). The publication and distribution of development studies research takes place in a scientific context dominated by a small group of top institutions in developed countries because of complex systemic processes which affect all academic fields (Cummings and Hoebink, 2017; Dahdouh-Gubas et al., 2003). In this respect, the domain of international development studies advances perspectives on participation and bridging inequalities while the knowledge production and use mechanisms in the domain often fail to consider and apply these perspectives in their own knowledge-related practices.

\section{A systemic approach to the decolonisation of knowledge}

Decolonisation of knowledge aims to challenge the hegemonic Eurocentric, Western knowledge system in which 'Western knowledge is considered universal and it is widely accepted that assumptions rooted in European modernity are applicable in different contexts' (Schöneberg, 2019, p. 97). According to Heleta (2018, p. 48), 'Decolonisation of knowledge implies the end of reliance on imposed knowledge, theories and interpretations, and Theorising based on one's own past and present experiences and interpretation of the world.' If the current knowledge system is fundamentally subject to coloniality, the ability to bring about systems change is limited by the way we 'breathe' coloniality-in the sense that much of it will be tacit and implicit-but also by the fact that the knowledge system itself represents a complex system, and that complex systems are characterized by many embedded interests which are not conducive to change (Leeuwis et al., 2020). As Istratii and Lewis (2019, p. 4) remark, 'colonial continuities that reflect in ways of knowing and theoretical thinking are underpinned by structural and normative factors and are perpetuated by a matrix of actors and processes simultaneously and in complex ways, not always intentional.'

In an effort to shed light on the entrenched patterns of knowledge coloniality and outline a roadmap toward more inclusive, representative, useful, and empowering constructions for development studies, we employ the multi-level perspective (MLP) to innovation systems, originating from the work of Geels (2002, 2005) and others. The MLP approach can reveal how sociotechnical 


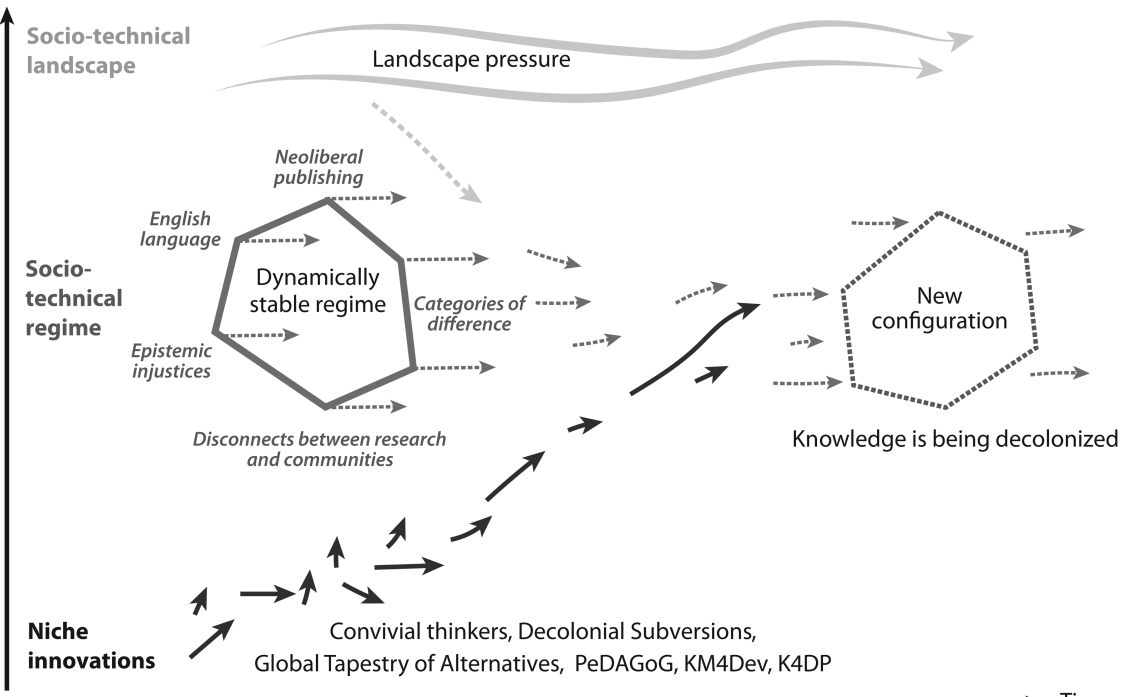

FIGURE 4.1 Multi-Level Perspective (MLP) (adapted from Schot and Geels 2008)

systems change over time by modelling the interaction of three analytical levels: first, the macro-level sociotechnical landscape which is beyond the direct influence of change agents (Grin et al., 2010), but includes societal trends that can put pressure on regimes and make them more liable to change; second, the meso-level sociotechnical regime which includes the dominant approach and is resistant to change because it is conditional on the landscape, including coloniality and the modern institutions of the university and academic publishing; and third, micro-level niches which are protected spaces where new ways of working are developed (see Figure 4.1). Within this model, system change is driven by change agents, in combination with landscape pressures, regime destabilisation processes, and 'upscaling' of innovations developed in niches (Wieczorek, 2018). This framework provides a useful perspective for efforts to understand and potentially change the current knowledge system because it recognises the power of actors to bring about change, while implicitly acknowledging the difficulties of changing this complex system.

At the sociotechnical regime level, there are enormous numbers of different, interlinked inequalities in the knowledge system, strongly linked to coloniality. We describe some of the most important of these below. There is no hierarchy in this description because they are strongly interlinked.

\section{Neo-liberal publishing}

At the landscape level, the prevailing neo-liberal economic system has an enormous impact at the regime level on university, research, and scientific 
publishing. As the journalist Monbiot (2011) explains, scientific publishers are 'the most ruthless capitalists in the Western world.' Given that journals are published behind paywalls that limit access, many scholars in formerly colonised countries are not able to legally access them. In addition, despite the fact that academic research could legitimately be viewed as a global public good, development practitioners are also not able to easily access these journals, leading to a situation where 'we have the development practitioners, who can't afford $£ 2,000$ for a journal [subscription] and academics, who are working separately' (Jha, 2012).

\section{Disconnects between research and communities}

The gap between development research and development practice (Edwards, 1989; Kothari, 2019, p. 4) is also amplified by disconnects between theory and communities, reflecting a 'fundamental perversity underpinning Western epistemology' (Istratii and Lewis, 2019, p. 2). Disconnects between research and communities are also evident in extractive research practices in which 'marginalised peoples frequently have no voice in the research or education that impacts them, while privileged others co-opt the right to define and describe their lives, their learning, and their identities' (Kouritzin and Nakagawa, 2018, p. 676).

\section{English language}

Some $75-90 \%$ of the research literature from the social sciences/humanities and natural sciences is published in English to the detriment of other international languages (Hamel, 2007, p. 53). Not only does this trend towards monolingualism benefit research institutions and individuals in English-speaking countries, as reflected in the authors and editorial boards in journals in the field of development studies (Cummings and Hoebink, 2017), it is also part of a process begun during colonialism in which African writers and intellectuals were also compelled to write in English. Ngũgĩ wa Thiong'o (1986, p. 286), a Kenyan thinker and writer, considers that 'language was the most important vehicle through which [colonial] power fascinated and held the soul prisoner.' This situation contributes to 'neglecting non-Western conceptual repertoires and understandings of the world and humanity' (Istratii and Lewis, 2019, p. 2) which is strongly linked to a series of epistemic injustices.

\section{Epistemic injustices}

A wide range of epistemic injustices have been identified by scholars, based on the perspective that 'far from being the apolitical study of truth, epistemology points to the ways in which power relations shape who is believed and why' (Collins, 2000, p. 252). Fricker (2007) is credited as distinguishing between two kinds of epistemic injustice: testimonial injustice and hermeneutical injustice. 
Testimonial injustice comprises attributing too little or too much credibility to a testimony due to identity prejudice on the hearer's part, often related to intersectional racial, class, and gender identity; for example, testimonial injustice is a 'candidate explanation for some of the existing forms of racial disparity found in financial services' (de Bruin, 2019, p. 1). Hermeneutical injustice is 'where a socially disadvantaged group is blocked-whether intentionally or unintentionally-from access to knowledge, or access to communicating knowledge (to those in more socially privileged locations) due to a gap in hermeneutical resources, especially when these resources would help people understand the very existence and nature of the marginalisation' (McKinnon, 2016, p. 441). However, according to McKinnon (2016), attributing these concepts to Fricker also represents a form of epistemic injustice because 'in a deep irony, while Fricker's work is extremely important in detailing the concept and structure of epistemic injustice, this topic finally achieved wider uptake with Fricker's work [...] but the large body of, primarily, black feminist thought isn't acknowledged' (McKinnon, 2016, p. 439).

There are different types of ignorance or 'unknowing' associated with hermeneutical ignorance. When this unknowing is intentional, it is known as 'wilful hermeneutical ignorance' in which 'dominantly situated knowers refuse to acknowledge epistemic tools developed from the experienced world of those situated marginally. Such refusals allow dominantly situated knowers to misunderstand, misinterpret, and/or ignore whole parts of the world' (Pohlhaus Jr., 2012, p. 715).

\section{Categories of difference}

In this section, we consider two categories of difference that exist at the landscape level-namely, race and gender-while recognising the importance of intersectionality which we will discuss further below. According to Patel (2020), the issue of race has largely been ignored in development studies, despite considerable literature on its historical and contemporary effects, numerous movements to decolonise the university, and recognition that race is directly relevant to both decolonisation and development. Kothari (2006, p. 9) also considers that "understanding development in terms of "race" can spotlight inadequacies, contradictions and misrepresentations in development ideologies, policies and practices, as well as relations of power.' Indeed, it appears that widespread calls to decolonise universities may have 'further embedded rather than dismantled whiteness' (Doharty et al., 2021, p. 1). Doherty and colleagues take a Critical Race Theory method of counter-storytelling to identify institutional racism, racial 'microaggression,' racial battle fatigue, and steadfast fugitive resistance in British higher education. Other commentators use a wider brush and argue that the development sector is 'reluctant - make that adamantly opposed — to placing a focus on race and racism in the aid sector [...] allowing larger systemic problems to go unchallenged' (Bruce-Raeburn, 2017). Race and gender as categories 
of difference are interlinked. For example, a study of 20 British and US public health universities demonstrated that "clear gender and ethnic disparities remain at the most senior academic positions, despite numerous diversity policies and action plans reported' (Khan et al., 2019, p. 594).

Dominance of the English language, a variety of epistemic injustices, the neo-liberal economic system, racism, and other inequalities interact to create a knowledge system that is unequal, subject to coloniality, and resistant to change. In the next section, we consider what scholars from Western donor countries can do to 'walk the walk' and be part of the solution.

\section{What can scholars from Western donor countries do?}

'How are you [our emphasis] de-centring the "white gaze" of development?' (Pailey, 2020, p.742).

'I call on over-represented people in science who are expressing outrage about racism in broader society to focus the same level of energy on looking inwards, to wake up to how the culture in academic science is exclusionary' (Bumpus, 2020, p. 661).

In this final part of the chapter, we look at ways in which scholars from Western donor countries can work in niches to engage with the decolonisation of knowledge in order to avoid acting with 'wilful hermeneutical ignorance.' Although we recognise that the current status of the knowledge system is the result of embedded systemic issues which are subject to historical, landscape issues beyond the control of individuals, scholars represent an important group of actors in this field: together, they can make a difference. This means that academics need to become activists, so that the decolonisation of knowledge moves away from becoming a theoretical project, to becoming an activist one. This involves working in transformative niches, developing new epistemologies and new ways of working.

\section{Working in niches}

'Why not also commit to speak only at scientific conferences and on panels that feature Black voices or those from other historically marginalized groups?' (Bumpus, 2020, p. 661).

Changes to sociotechnical regimes-such as the current colonial knowledge system - are assumed to take place in two ways: through action in niches, and through changes due to external forces. There are currently a number of niches where academics are trying to work in new ways to create decolonial narratives. These include an open group of scholars known as the Convivial Thinkers, ${ }^{2}$ an initiative of four European women scholars with links to the European 
Association for Development Research and Training Institutes (EADI), working and writing on issues related to post- and decolonial approaches. Another decolonial project comprises the new journal Decolonial Subversions, an open access, multilingual platform committed to decentring Western epistemology in the humanities and social sciences, based at the School of Oriental and African Studies (SOAS), University of London, UK. But there are many others, such as the Global Tapestry of Alternatives ${ }^{3}$, which focuses on radical or transformative alternatives that are attempting to break with the dominant system and take paths towards direct and radical forms of political and economic democracy, localised self-reliance, social justice and equity, cultural and knowledge diversity, and ecological resilience. It represents a network of networks, while seeking to connect with other networks. It is also linked to PeDAGoG: the Post-Development Academic-Activist Global Group ${ }^{4}$, a global network of academics and academicactivists interested in post-development, radical alternatives, and related themes, initiated in early 2020. Other networks, such as the Knowledge Management for Development (KM4Dev) community ${ }^{5}$ and the Knowledge for Development Partnership (K4DP) ${ }^{6}$, are also attempting with others to 'decolonise' knowledge management. There are many more of these sorts of spaces but decolonisation will only be achieved if these niches are activist in nature and if they work together.

\section{Promising epistemologies}

At the niche level, intersectionality is another approach to dismantle racism and other inequalities in development studies. Intersectionality is 'a critical theoretical idea and an approach to research that aims to redress inequality by revealing and responding to the oppressions and privileges that result when peoples' identities or positions intersect with each other, and with social structures' (Levac et al., 2018, p. 8). It is based on the understanding that 'categories of difference' (Sosa, 2017, p. 16) such as gender, race, class, sexual orientation, age, ableness, and location, interact and cannot be seen as single entities. For example, "women of colour are not "doubly oppressed" based on a race-gender addition; they experience a new and different form of discrimination and are often not covered by the combination of policies and laws addressing single categories of subordination' (Sosa, 2017, p. 18). The origins of intersectionality can be found in 'black feminist scholarship, queer and postcolonial theory, Indigenous feminism, and other academic work addressing issues of race, class, gender and power' (Institute for Intersectionality Research and Policy, 2012, p. 11). Debates around intersectionality highlight 'epistemological questions about the relationship between the identity and interests of the individual knower and her contribution to scholarship at a micro-level, and how the composition of the scholarly community at a macro-level shapes which and whose questions, dimensions and contributions are prioritised' (Mügge et al., 2018, p. 18).

While the injustices of the dominant epistemic system are described above, framing this as an ethical issue potentially inadvertently reflects North-South 
relations of domination. Decolonisation of knowledge is not only about academics from Western donor countries realising that they should be more inclusive to other academics. Instead, decolonization is about all academics realising that knowledge production emanating from the Western donor countries rests on accidental, historical power relations of domination that legitimise themselves via unsound claims of universal reason. At the niche level, decolonisation of knowledge calls for a radical openness and vulnerability to disempowered constructions, in order to offset the 'distorting and exclusionary effects of domination' (Allen, 2016, p. 224). This change represents progress toward more inclusive, representative, useful, and empowering constructions. It is in the spirit of this progress that we

enter into intercultural dialogue with subaltern subjects without presuming that we already know what the outcome of that dialogue should be, that is to say, with an openness to the very real possibility of unlearning. Indeed, both Foucault and Adorno see a kind of unlearning-a critical problematization of our own, historically sedimented point of view that frees us up in relation to it - as the very point of critique.

(Allen, 2016, p. 203-204)

There is no doubt that new epistemologies are needed to replace the "paternalistic and patronising undercurrents of an earlier period' (Melber, 2015). Based on an analysis of the debate 'Can the subaltern speak?' (Spivak, 1988), Schöneberg considers that development knowledge needs to be retheorised to involve varied epistemological frameworks and further consideration of indigenous and non-Western knowledges. There are many scholars taking up this challenge-for example, Brown's conception of multiple knowledge (Brown, 2011) - but an overview of these different approaches is probably needed in order to understand how these niche innovations can impact the sociotechnical regime.

\section{New ways of working}

New Information and Communication Technologies (ICTs) could play a role in decolonising knowledge-related practices in the development studies field. These technologies have revolutionised how people connect and interact, and therefore present opportunities to influence or improve communication aspects of service delivery (Martin and Hall, 2011). These technologies' capabilities are especially of issue in the Covid-19 era in which online engagement is taking precedence over face-to-face engagement. Mentorship and networking are knowledge-related practices that new ICTs may also impact. Through online skills development, lectures, talks, and networking events, academics from Western donor countries can connect with scholars in formerly colonised countries to provide mutual support and perspectives. Alternatively, such fora may 
be used by African scholars to provide their perspectives on global development issues. Furthermore, these forays can also serve as contextual review events that can also enable scholars from Western donor countries to broaden their engagement with scholars outside their context, and to identify possible partners for inclusion on editorial boards, joint publications, or to engage as guest lecturers in courses. As Acosta-Cazares et al. (2000) note, with ' $[\mathrm{t}]$ he possibility of easier communication that the internet brings about, it would also have a favourable impact in developing countries because researchers and health care personnel could be in direct contact before and after starting a study.' At the same time, scholars in the field of development studies need to understand more of the knowledge practices which are excluding their colleagues from scientific journals, university appointments, and other academic spaces (Khan et al., 2019), and agitate for change through working with like-minded colleagues and through their own actions.

\section{New discourses}

Recent studies have also emphasised that the discourse in development studies is characterised by 'separating, distancing, dominating, extracting and hoarding riches, and justifying actions by "othering"' mindsets, influenced by a 'colonial, imperial, unequal, patriarchal' legacy (Hendrix-Jenkins 2020). In an online discussion with colleagues in the KM4Dev network, Kishor Pradhan argues that 'the discomfort with the racial and colonial supremacy of language is not about processes or results but if anything then it is about dignity and equality' (communication, 28 August 2020). Many scholars, such as Pailey (2020, p. 734), emphasise the importance of abandoning problematic binaries in development studies, such as 'developing vs developed, industrial vs agrarian, low income vs high income, Third World vs First World, Global South and Global North, core vs periphery, sub-Saharan Africa vs North Africa, etc. [...] These binaries shackle us, they do not liberate.' In this context, some commentators consider that the term 'international development,' based on the North-South binary, appears to be inappropriate for addressing the major challenges facing the world; Horner (2020) and others consider that 'global development' should be the new paradigm to replace international development, recognising that 'we are all developing countries now' (Raworth, 2018), along with the need for universal approaches to deal with, for example, climate change. Others have suggested we use 'formerly colonised countries' instead of 'the global South" which could call attention to the continuous impact of colonialism, and disrupt development's effort to conceal its colonial roots. Attempting to follow this line of argumentation, and in an effort to strive for dignity and equality, in this chapter we have replaced the term 'global North' with the term 'Western donor countries' and 'global South' with the 'formerly colonised countries.' We are not sure that this has been successful but it reflects the historical nature of global development and is a work in progress. 


\section{Changing our practice}

Against this background, scholars from Western donor countries need to recognise that they are implicit in this unequal knowledge system and change their own practices, particularly given new insights. For example, Michael Hutt, Professor of Nepali and Himalayan Studies, speaking at the SOAS Decolonising Research Initiative event on 18 September 2019, explained: 'I published this book on Nepal in the Nineties on political change, and all of the chapters were written by nonNepali's and deservedly I got hammered in a review by Pratyoush Onta [...] and 24 years later Praytoush and I jointly edited [Political change and public culture in post-1990 Nepal].' As researchers, writers, editorial board members, and editors, we need to oppose current knowledge practices when we feel they are unequal.

\section{Conclusions}

In this chapter, we have discussed some of the key systemic issues that are responsible for coloniality as it relates to knowledge, and highlighted some of the approaches that scholars can take to disrupt coloniality and support the decolonisation of knowledge. We recognise that other actors-both groups of individuals and institutional actors - can play an important role in decolonising knowledge but scholars themselves also need to take action and avoid the charge of willful hermeneutical ignorance. Although there are many different niche activities which are challenging current knowledge practices, their apparent focus on promising epistemologies and new ways of working can be augmented with an activist approach.

\section{Acknowledgements}

We would like to thank the editors of this book for their support in the process of formulating and writing this chapter. We would also like to thank Katarzyna Cieslik and Cees Leeuwis for their detailed feedback and discussions which have helped us to improve the chapter; the shortcomings remain our own.

\section{Notes}

1 https://drift.eur.nl/topics/transformative-knowledge/.

2 https://www.convivialthinking.org/=

3 https://globaltapestryofalternatives.org/.

4 https://globaltapestryofalternatives.org/pedagog.

5 www.km4dev.org.

6 www.k4dp.org.

7 https://gen.medium.com/i-spent-much-of-my-career-listening-to-white-folks-c omplain-about-africa-and-africans-88cc677f3a3.

\section{References}

Acosta-Cazares, B., Browne, E., LaPorte, R. E., Neuvians, D., de Camargo, K. R., Tapia-Conyer, R. and Ze, Y. (2000). Scientific colonialism and safari research. 
Clinical Medicine and Health Research, BMJ. Accessed 5 October, 2020. https://staticw eb.bmj.com/clinmed/content/2000/200001/fulltext/2000010008v1/200001000 8v1.htslp

Allen, A. (2016). The end of progress, decolonizing the normative foundations of critical theory. New York: Columbia University Press.

Arce, A. and Long, N. (1987). The dynamics of knowledge interfaces between Mexican agricultural bureaucrats and peasants: A case study from Jalisco. Boletín de Estudios Latinoamericanos y del Caribe, 43, 5-30.

Broadbent, A. (2017). It will take critical, thorough scrutiny to truly ecolonize knowledge. The Conversation. https://theconversation.com/it-will-take-criticalthorough-scrutiny-to-truly-decolonise-knowledge-78477

Brown, V. A. (2011). Multiple knowledges, multiple languages: Are the limits of my language the limits of my world? Knowledge Management for Development Journal, 6(2), $120-131$.

Bruce-Raeburn, A. (2017). Opinion: International development has a race problem. DEVEX, 17, May 2019. Accessed 5 August 2020. https://www.devex.com/news/opi nion-international-development-has-a-race-problem-94840

de Bruin, B. (2019). Epistemic injustice in finance. Topoi, 1-9. Doi:10.1007/ s11245-019-09677-y

Bumpus, N. (2020). Too many senior white academics still resist recognizing racism. Nature, 583(7818), 661.

Busia, K. A. (1960). The sociology and culture of Africa: Its nature and scope. Universitaire Pers.

Chandra, R. (1992). Industrialisation and development in the Third World. London: Routledge.

Collins, P. H. (2000). Black feminist thought: Knowledge, consciousness, and the politics of empowerment. London: Routledge.

Cooke, B. (2003). A new continuity with colonial administration: Participation in development management. Third World Quarterly, 24(1), 47-61.

Cummings, S. and Hoebink, P. (2017). Representation of academics from developing countries as authors and editorial board members in scientific journals: Does this matter to the field of development studies? European Journal of Development Research, 29(2), 369-383.

Dahdouh-Guebas, F., Ahimbisibwe, J., van Moll, R. and Koedam, N. (2003). Neocolonial science by the most industrialised upon the least developed countries in peerreviewed publishing. Scientometrics, 56(3), 329-343.

Demeter, M. (2020). Academic knowledge production and the Global South: Questioning inequality and under-representation. New York: Palgrave Macmillan.

Doharty, N., Madriaga, M. and Joseph-Salisbury, R. (2021). The university went to 'decolonise'and all they brought back was lousy diversity double-speak! Critical race counter-stories from faculty of colour in 'decolonial' times. Educational Philosophy and Theory, 53(3), 233-244.

Edwards, M. (1989). The irrelevance of development studies. Third World Quarterly, 11(1), 116-135.

Fricker, M. (2007). Epistemic injustice: Power and the ethics of knowing. Oxford: Oxford University Press.

Geels, F. (2002). Technological transitions as evolutionary reconfiguration processes: a multi-level perspective case-study. Research Policy, 31(8/9), 1257-1274.

Geels, F. (2005). Processes and patterns in transitions and system innovations: refining the co-evolutionary multi-level perspective. Technological Forecasting and Social Change, 72(6), 681-696. 
Goldsmith, E. (1997). Development as colonialism. The Ecologist, March/April, 27(2), 69-77.

Grin, J., Rotmans, J. and Schot, J. (2010). Transitions to sustainable development: New directions in the study of long term transformative change. London: Routledge.

Hamel, R. E. (2007). The dominance of English in the international scientific periodical literature and the future of language use in science. AILA Review, 20(1), $53-71$.

Heleta, S. (2018). Decolonizing knowledge in South Africa: Dismantling the 'pedagogy of big lies'. Ufahamu: A Journal of African Studies, 40(2), 47-65.

Hendrix-Jenkins, A. (2020). It's time to put an end to supremacy language in international development. Accessed 5 October 2020. https://www.opendemocracy.net/en/tr ansformation/its-time-to-put-an-end-to-supremacy-language-in-internationaldevelopment/

Horner, R. (2020). Towards a new paradigm of global development? Beyond the limits of international development. Progress in Human Geography, 44(3), 415-436.

Institute for Intersectionality Research and Policy (2012). Summary of themes: Dialogue on intersectionality and indigeneity. Wosk Centre for Dialogue, Institute for Intersectionality Research and Policy.

Istratii, R. and Lewis, A. (2019). Applying a decolonise lens to research structures, norms and practices in higher education institutions. Conversation event report, SAAS University of London, Research and Enterprise Directorate.

Jha, A. (2012). UK government will enforce open access to development research. The Guardian, 25 July 2012. Accessed 6 April, 2016. https://www.theguardian.com/sc ience/2012/jul/25/uk-government-open-access-developmentresearch

Khan, M. S., Lakha, F., Tan, M. M. J. et al. (2019). More talk than action: Gender and ethnic diversity in leading public health universities. The Lancet, 393(10171), 594-600.

Kothari, U. (2006). An agenda for thinking about 'race' in development. Progress in Development Studies, 6(1), 9-23.

Kothari, U. (2019). A radical history of development studies: Individuals, institutions and ideologies. London: Zed Books.

Kouritzin, S. and Nakagawa, S. (2018). Toward a non-extractive research ethics for transcultural, translingual research: Perspectives from the coloniser and the colonised. Journal of Multilingual and Multicultural Development, 39(8), 675-687.

Levac, L., McMurtry, L., Stienstra, D., Baikie, G., Hanson, C. and Mucina, D. (2018). Learning across indigenous and Western knowledge systems and intersectionality. Canadian Research Institute for the Advancement of Women. Accessed 5 October 2020. https://www.criaw-icref.ca/en/product/learning-across-indigenous-and-w estern-knowledge-systems

Leeuwis, C., Boogaard, B. and Attah Krah, K. (2020) How food systems change (or not): Governance implications for system transformation processes. Draft paper, International Fund for Agricultural Development (IFAD).

Mafeje, A. (1978). Science, ideology and development: Three essays on development theory. Uppsala: Scandinavian Institute of African Studies. Accessed 15 September 2020. https://www.diva-portal.org/smash/get/diva2:275758/FULLTEXT02.pdf

Martin, B. L. and Hall, H. (2011). Mobile phones and rural livelihoods: Diffusion, uses, and perceived impacts among farmers in rural Uganda. Information Technologies \& International Development, 7(4), 17-34.

McEwan, C. (2009). Postcolonialism and development. London: Routledge.

McKinnon, S. L. (2016). Gendered asylum: Race and violence in U.S. law and politics. Champaign: University of Illinois Press. Accessed 28 July 2020. http://search.ebscoh 
ost.com.ezproxy.library.wur.nl/login.aspx?direct $=$ true $\& d b=$ nlebk $\& A N=1423207$ $\&$ site $=$ ehost-live.

Melber, H. (2015). Knowledge is power and power affects knowledge: Challenges for research collaboration in and with Africa. Africa Development/Afrique et Développement, 40(4), 21-42.

Miege, J. L. (1980). The colonial past in the present. In: Morris-Jones, W. H. and Fischer, G. (eds.), Decolonisation and after: The British and French experience. London: Frank Cass.

Mignolo, W. (1995). Decires fuera de lugar: sujetos dicentes, roles sociales y formas de inscripción. Revista de Crítica Literaria Latinoamericana, 11, 9-32.

Monbiot, G. (2011). Academic publishers make Murdoch look like a socialist. The Guardian, 29 August. Accessed 11 August 2020. https://www.theguardian.com/co mmentisfree/2011/aug/29/academic-publishers-murdoch-socialist

Mügge, L., Montoya, C., Emejulu, A. and Weldon, S. L. (2018). Intersectionality and the politics of knowledge production. European Journal of Politics and Gender, 1(1-2), $17-36$.

Ndlovu-Gatsheni, S. J. (2019). The struggles of epistemic freedom and decolonization of knowledge in Africa. Webinar Lecture delivered at the Convivial Thinking Collective in Collaboration with European Association of Development Research and Training Institutes (EADI), 12 March 2019. Accessed 27 July 2020. https://www.eadi.org/ typo3/fileadmin/user_upload/Webinars/EADI_Webinar_12_-_The_Struggles_of _Epistemic_Freedom_and_Decolonization_of_Knowledge_in_Africa__2019-03 $-12 \_. p d f$

Ngũgĩ wa Thiong'o (1986). Decolonising the mind: The politics of language in African literature. Melton: James Currey.

Nkrumah, K. (1961). I speak of freedom: A statement of African ideology. Portsmouth: Heinemann.

Okot p'Bitek (1997). Indigenous ills. Transition, 75-76, 40-42.

Oliveira Andreotti, V., de, Stein S., Ahenakew, C. and Hunt, D. (2015). Mapping interpretations of decolonization in the context of higher education. Decolonization: Indigeneity, Education \& Society, 4(1), 21-40.

Pailey, R. N. (2020). De-centring the 'white gaze' of development. Development and Change 51(3), 729-745.

Patel, K. (2020). Race and a decolonial turn in development studies. Third World Quarterly, 41(9), 1463-1475.

Pohlhaus Jr., G. (2012). Relational knowing and epistemic injustice: Toward a theory of willful hermeneutical ignorance. Hypatia, 27(4), 715-735.

Raworth, K. (2018). Doing the Doughnut at the G20?' Blog, 1 December 2018. www.k ateraworth.com/2018/12/01/doing-the-doughnut-at-the-g20/

Said, E. W. (1979). Orientalism. 1st edition. New York: Vintage Books.

Schöneberg, J. (2019). Imagining postcolonial-development studies: Reflections on positionalities and research practices. In: Baud, I., Basile, E., Kontinen, T. and Von Itter, S. (eds.). Building development studies for the new millennium. Dordrecht: Springer.

Schot, J. and Geels, F. W. (2008). Strategic niche management and sustainable innovation journeys: Theory, findings, research agenda, and policy. Technology Analysis \& Strategic Management, 20(5), 537-554. Doi:10.1080/09537320802292651

Sosa, L. (2017). Intersectionality in the human rights legal framework on violence against Women: At the centre or the margins? Cambridge: Cambridge University Press.

Spivak, G. C. (1988). Can the subaltern speak? In: Nelson, C. and Grossberg, L. (Eds.). Marxism and the interpretation of culture. Champaign: University of Illinois Press, 271-313. 
Torres, N. (2007). On the coloniality of being: Contributions to the development of a concept. Cultural Studies, 21(2), 240-270.

Wieczorek, A. J. (2018). Sustainability transitions in developing countries: Major insights and their implications for research and policy. Environmental Science and Policy, 84, 204-216. 